\title{
Vancomycin loading dose is associated with increased early clinical responses without attainment of initial target trough concentration at a steady state in patients with normal renal function
}

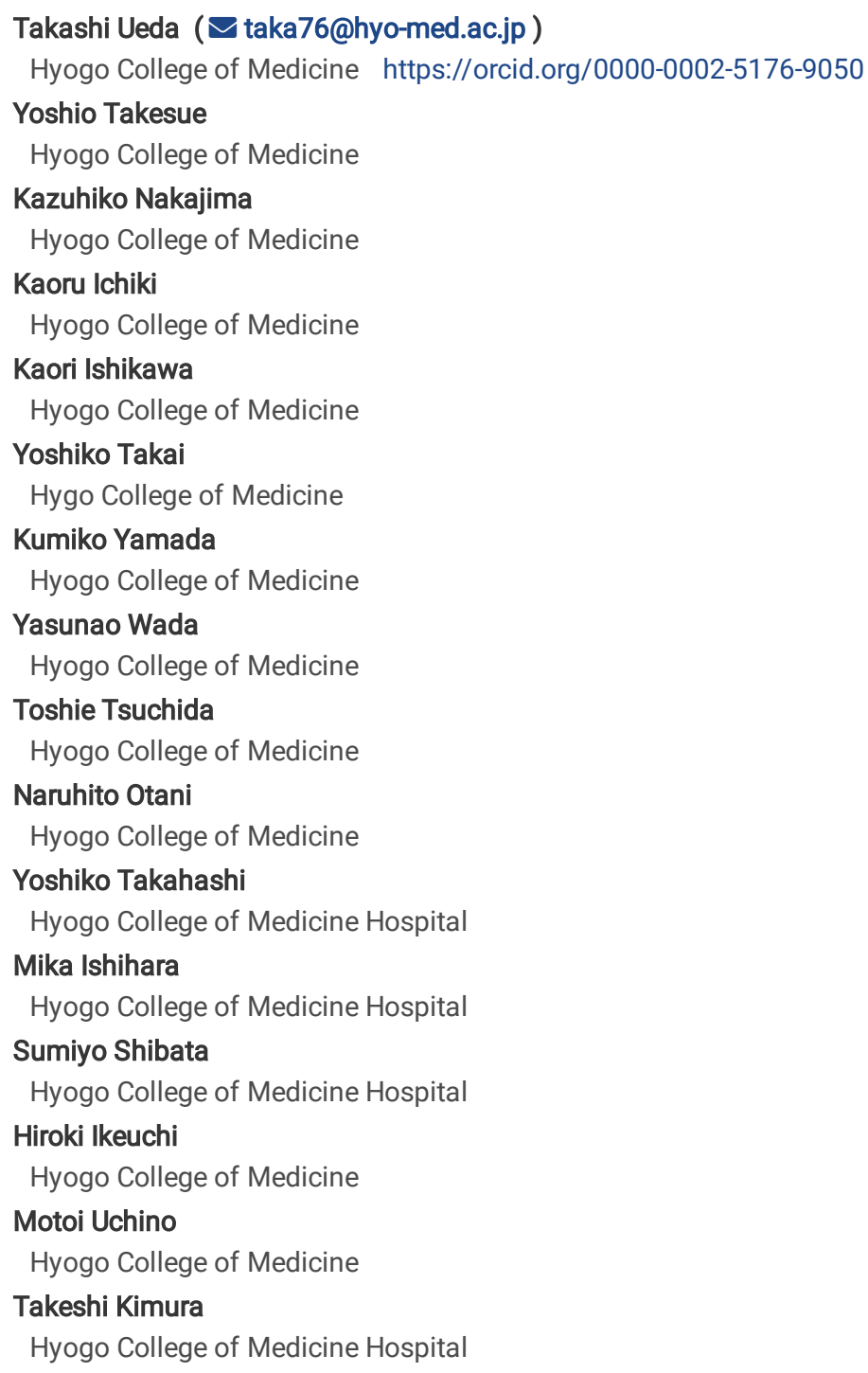

Research article

Keywords: vancomycin, a loading dose, trough concentration, clinical efficacy, therapeutic drug monitoring

Posted Date: July 3rd, 2019

DOI: https://doi.org/10.21203/rs.2.10949/v1

License: () (1) This work is licensed under a Creative Commons Attribution 4.0 International License. Read Full License 


\section{Abstract}

Background Vancomycin therapeutic guidelines suggest a loading dose of $25-30 \mathrm{mg} / \mathrm{kg}$ for seriously ill patients. However, high-quality data to guide the use of loading dose are lacking. Evaluate whether a loading dose 1) achieves a target trough concentration (Cmin) at steady state and 2) improves early clinical responses. Methods Patients with an estimated glomerular filtration rate $\geq 90 \mathrm{~mL} / \mathrm{min} / 1.73 \mathrm{~m} 2$ were included. A loading dose of $25 \mathrm{mg} / \mathrm{kg}$ vancomycin followed by $15 \mathrm{mg} / \mathrm{kg}$ twice daily was compared with traditional dosing. A Cmin sample was obtained before the fifth dose. An early clinical response $48-72 \mathrm{~h}$ after the start of therapy and clinical success at end of therapy (EOT) was evaluated in patients with methicillinresistant Staphylococcus aureus (MRSA), methicillin-resistant coagulase-negative Staphylococci, or Enterococcus faecium. Results There was no significant difference in $\mathrm{Cmin}$ between the regimen with and without a loading dose (median: $10.4 \mu \mathrm{g} / \mathrm{mL}$ and $10.2 \mu \mathrm{g} / \mathrm{mL}, \mathrm{P}=0.538$ ). Proportions of patients achieving $10-20 \mu \mathrm{g} / \mathrm{mL}$ and $15-20 \mu \mathrm{g} / \mathrm{mL}$ were $56.9 \%$ and $5.6 \%$, respectively, in patients with a loading dose. Although there was no significant difference in success rate at EOT between groups, loading dose was associated with increased early clinical responses for all infections [adjusted odds ratio (OR): 4.829, 95\% confidence interval (Cl): 1.441-16.188] and MRSA infections (OR: 10.851, 95\% Cl: 1.701-69.233). Increased adverse events were not observed with the loading dose. Study limitations included no $\mathrm{Cmin}$ measurements within 24 hours, and the inclusion of less critically ill patients. Conclusions Although the loading dose did not achieve optimal $\mathrm{Cmin}$ at steady state, a higher early clinical response was obtained compared with traditional dosing.

\section{Background}

Although the incidence of methicillin-resistant Staphylococcus aureus (MRSA) infections has gradually decreased over the past decade [1, 2], MRSA remains one of the most prevalent resistant organisms in health care associated infections [3]. Vancomycin is a commonly used antibiotic for the treatment of MRSA infections. The optimization of vancomycin dosing is important and a target trough concentration $\left(C_{\min }\right)$ of $10-20 \mu \mathrm{g} / \mathrm{mL}$ has been proposed [4,5]. The $C_{\min }$ should be maintained above $10 \mu \mathrm{g} / \mathrm{mL}$ to avoid the development of resistance [6]. A $C_{\min }$ of $15-20 \mu \mathrm{g} / \mathrm{mL}$ improved outcomes in patients with complicated MRSA bacteremia [7].

Vancomycin is commonly initiated at a standard dose of $15 \mathrm{mg} / \mathrm{kg}$ every $12 \mathrm{~h}$ with dosage adjustment based on creatinine clearance $\left(\mathrm{CL}_{\mathrm{cr}}\right)[4,5]$. However, with the same dosage regimen, the median $C_{\min }$ remained $9.4 \mu \mathrm{g} / \mathrm{mL}(62 \%$ of patients were $<10 \mu \mathrm{g} / \mathrm{mL}$ ) on day 3 of a study for the treatment of complicated skin and soft tissue infections caused by MRSA [8]. In a randomized trial for the treatment of nosocomial pneumonia caused by MRSA, the median $C_{\min }$ on day 3 was $12.3 \mu \mathrm{g} / \mathrm{mL}$, and $25 \%$ of patients had a $C_{\min }<7.9 \mu \mathrm{g} / \mathrm{mL}$ [9]. The standard dosing regimen was inadequate at achieving the target $\mathrm{C}_{\min }$ [10]. In patients with sepsis, fluid extravasation causes an increase in interstitial volume. For hydrophilic antibiotics such as vancomycin, these pathophysiological changes might increase the volume of distribution and cause low antibiotic serum concentration [11]. Therefore, initial loading is important to avoid the risk of underexposure.

Vancomycin therapeutic guidelines $[4,5]$ suggest a loading dose of $25-30 \mathrm{mg} / \mathrm{kg}$ for seriously ill patients. However, high-quality data to guide the use of loading dose are lacking. In a systematic review, Reardon et al. [12] suggested that a loading dose may attain target $C_{\min }$ of $15-20 \mu \mathrm{g} / \mathrm{mL}$. However, they included studies that evaluated efficacy of dosing nomogram or which assessed early concentrations before steady state. The aim of this study was to evaluate the efficacy of a loading dose to achieve the target $\mathrm{C}_{\min }$ at a steady state in patients with normal renal function. A second aim was to evaluate early clinical responses [13] obtained by the loading dose, because it is intended to achieve a rapid attainment of optimal concentrations, and clinical responses can be affected by a change in vancomycin dose later in therapy.

\section{Methods}

Patients and protocol

This study was conducted between April 2011 and May 2018. Adult patients with an estimated glomerular filtration rate (eGFR) of $\geq 90 \mathrm{~mL} / \mathrm{min} / 1.73$ $\mathrm{m}^{2}$ who were treated with vancomycin, and in whom therapeutic drug monitoring (TDM) was performed, were included in the study. Exclusion criteria were patients with known hypersensitivity to vancomycin, pregnancy, below the age of 18 years, and body weight of $\geq 100 \mathrm{~kg}$. Retrospective evaluation of the regimen without a loading dose was conducted between April 2011 and December 2015, and the evaluation of the regimen with a loading dose of $25 \mathrm{mg} / \mathrm{kg}$ was conducted between January 2016 and May 2018. A maintenance dose of $15 \mathrm{mg} / \mathrm{kg}$ every $12 \mathrm{~h}$ was administered to both regimens. An initial $\mathrm{C}_{\min }$ sample was obtained before the fifth dose. Vancomycin concentration was measured using a commercial reagent kit (Vanc Flex; Siemens Healthcare Diagnostics, Tokyo, Japan).

The analysis of safety population included all eligible patients. For the $\mathrm{C}_{\min }$ evaluation, patients whose renal function deteriorated from the initiation of vancomycin to the initial TDM were excluded. The analysis of clinical efficacy population included patients who had infections with MRSA, methicillin-resistant coagulase-negative Staphylococci (MR-CNS) or Enterococcus faecium, who received at least 3 days of vancomycin treatment, who did not receive any concomitant antibiotics with anti-MRSA activity, and who did not receive the above mentioned antibiotics for $>24 \mathrm{~h}$ within the previous 3 days. The diagnosis of each type of infection, other than respiratory tract infection, was based on the definitions of the guidelines issued by the National Healthcare Safety Network. (CDC/NHSN surveillance definitions for surgical site infections. Centers for Disease Control and Prevention website: http://www.cdc.gov/nhsn/pdfs/pscmanual/17pscnosinfdef_current.pdf. Published 2018. Accessed November 10, 2018.). 
Infections with at least one of the following signs were analyzed: core temperature $>37.8^{\circ} \mathrm{C}$, total peripheral white blood cell (WBC) count $>10,000$ $/ \mathrm{mm}^{3}$, or C-reactive protein (CRP) $>3.0 \mathrm{mg} / \mathrm{dL}$. Diagnosis of pneumonia was defined as chest X-rays or CT scans consistent with pneumonia and at least two of the following signs or symptoms: (new onset or worsening cough; purulent sputum or increased suctioning requirements; auscultatory findings of pneumonia; dyspnea, tachypnea, or respiratory rate ${ }^{3} 30$ min; hypoxemia; worsening gas exchange, and at least one of the inflammatory signs described above [9]. The MIC of vancomycin was measured by microdilution methods in accordance with the Clinical and Laboratory Standards Institute testing guidelines (M02 and M07, 2018) [14].

\section{Clinical efficacy}

The primary endpoint was set as an early clinical response at $48-72 \mathrm{~h}$ after the start of therapy. We defined patients as responders if they had a $30 \%$ or greater decrease in total peripheral WBC count or CRP, decline of fever (defined as a daily maximum temperature decrease of $>0.3^{\circ} \mathrm{C}$ for at least two consecutive days in febrile patients), without worsening of clinical features, and did not die within $96 \mathrm{~h}$. Secondary efficacy end points were clinical success at the end of vancomycin therapy (EOT), which was defined as survival with resolution or improvement in all core symptoms and signs of infection in each infection to the extent that further antibacterial therapy with anti-MRSA activity was unnecessary. Microbiological assessments were conducted using cultures taken before the start of vancomycin administration and at the completion of treatment, and microbiological success was defined as "eradication" (admission pathogen absent in culture) or "presumed eradication" (no material available for culture because of the infection site being cured or attenuated).

Adverse effects

Adverse effects of nephrotoxicity and hepatotoxicity were evaluated on the third day of therapy and at the end of vancomycin therapy. Nephrotoxicity was defined as a serum creatinine (Cre) increase $>0.5 \mathrm{mg} / \mathrm{L}$ or $50 \%$ increase from the baseline. Hepatotoxicity was defined as aspartate aminotransferase (AST) or alanine aminotransferase (ALT) levels at or above three times the upper limit of normal. If the AST or ALT baseline was abnormal, hepatotoxicity was defined as AST or ALT at or above three times the baseline.

Statistical analysis

Parametric variables were analyzed using the Student's $t$-test, while nonparametric variables were analyzed using the Mann-Whitney U-test or Fisher's exact test. Multivariate analyses were performed to determine the odds ratio (OR) for early clinical responses. The crude OR in univariate analysis was estimated for each variable with the chi-squared test, and potential confounders were examined by cross tabulation. Variables selected by univariate analysis $(\mathrm{P}<0.1)$ were subsequently entered into a stepwise logistic regression model to estimate the magnitude of association [adjusted OR and $95 \%$ confidence interval (CI)]. The level of significance was set at $\mathrm{P}<0.05$. SPSS ver. 24 (SPSS Inc., Chicago, IL, USA) was used to perform these analyses.

\section{Results}

\section{Baseline demographics}

Overall, 157 patients were included in the safety analyses. In the TDM evaluation, four patients with worsening renal function at the initial TDM after the start of vancomycin were excluded, and 153 patients were assessed. Among 95 patients who had MRSA, MR-CNS, or E. faecium infections, seven patients who did not receive at least 3 days of vancomycin treatment, and six patients who received any concomitant antibiotics with anti-MRSA activity were excluded from the clinically efficacy evaluation. No patient had an infection with vancomycin resistant enterococci. Overall, 82 patients were analyzed for early clinical responses, and 55 patients with MRSA infections were also analyzed. The initial loading dose was $25.7 \pm 0.9 \mathrm{mg} / \mathrm{kg}$. There was no significant difference in the maintenance dose between regimens with and without a loading dose (15.3 $\pm 0.5 \mathrm{mg} / \mathrm{kg}$ vs $15.2 \pm 0.6$ $\mathrm{mg} / \mathrm{kg}, \mathrm{P}=0.410$ ). Patient characteristics are shown in Table 1. Acute Physiology and Chronic Health Evaluation (APACHE) II scores were approximately $8.0-9.0$.

Measurements of $\mathrm{C}_{\min }$

The median $\mathrm{C}_{\min }$ was $10.4 \mu \mathrm{g} / \mathrm{mL}$ in the regimen with a loading dose, and $10.2 \mu \mathrm{g} / \mathrm{mL}$ in the regimen without a loading dose $(P=0.538)$. The proportion of patients achieving the target range $(10-20 \mu \mathrm{g} / \mathrm{mL})$ was $41 / 72(56.9 \%)$ in the regimen with a loading dose and $39 / 81(48.1 \%)$ in the regimen without a loading dose $(P=0.277)$. The higher target range of $15-20 \mu \mathrm{g} / \mathrm{mL}$ was achieved in only $4 / 72$ patients with a loading dose and $8 / 81$ patients without a loading dose $(P=0.321)$ (Table 2). Body mass index (BMI) was $25-30$ in 19 patients and $\geq 30$ in 3 patients. Achievement of 
the target $C_{\min }$ was obtained in $70 \%$ and $66 \%$ of obese/overweight patients and $54 \%$ and $44 \%$ of patients whose BMI was $<25$ in the regimens with and without a loading dose, respectively. After the initial TDM, dosage was increased in 28 patients and decreased in 11 patients, and vancomycin was discontinued in 33 patients. The proportion of patients achieving a $C_{\min }$ of $10-20 \mu \mathrm{g} / \mathrm{mL}$ was significantly increased from $54.3 \%$ to $78.7 \%$ $(P<0.001)$ in 94 patients who had follow-up TDM $(4.3 \pm 1.9$ days after initial TDM) and was increased from $7.4 \%$ to $74.1 \%$ of patients in whom the dosage was increased after initial TDM.

Clinical efficacy and mortality

Early clinical responses were obtained in 53/82 patients (64.6\%), and clinical success at EOT was obtained in 58/82 patients (70.7\%). The 28-day mortality rate was $6 / 82$ patients $(7.3 \%)$. In patients with a loading dose, the early clinical response rate tended to be higher compared with patients without a loading dose [27/36 (75.0\%) vs. 26/36 (56.5\%), P=0.082]. In MRSA infections, the early clinical response rate in patients with a loading dose was significantly higher than that in patients without a loading dose [18/23 (78.3\%) vs 16/32 (50.0\%), P=0.033]. However, there was no significant difference in the clinical success rate at EOT between the two regimens (all: $72.2 \%$ vs $69.6 \%, P=0.793 ;$ MRSA: 69.6\% vs 56.3\%, $\mathrm{P}=0.316$ ) (Table 3 ). The 28-day mortality rate was $8.3 \%$ in the regimen with a loading dose and $6.5 \%$ in the regimen without a loading dose (P=1.000), and $4.3 \%$ and $9.4 \%$ in patients with MRSA infections $(\mathrm{P}=0.632)$, respectively.

By univariate analysis, collagen disease, ICU stay, hypoalbuminemia, ventilator use, APACHE II score > 10, and respiratory tract infections were factors associated with a poor early clinical response in all clinical efficacy populations (Table 4). In patients with MRSA infections, collagen disease, total parenteral nutrition, ventilator use, APACHE II score $>10$, and steroid use were the factors associated with a poor early clinical response, and skin and skin-structure infections and loading dose were associated with a favorable early clinical response (Table 5). By multivariate analysis, a loading dose regimen was associated with an early clinical response in the whole clinical efficacy population (adjusted OR: 4.829, 95\% Cl: 1.441-16.188) and MRSA infection group (adjusted OR: 10.851, 95\% Cl: 1.701-69.233). The factors for a poor early clinical response were APACHE II score > 10 in the whole clinical efficacy population, and APACHE II score $>10$ and osteomyelitis/arthritis in MRSA infection group, respectively.

Adverse effects

In the assessment of safety population, there was no significant difference in the occurrence of nephrotoxicity between regimens with and without a loading dose [3.6\% and $1.4 \%$ on the third day $(P=0.624) ; 8.2 \%$ and $6.0 \%$ at EOT $(P=0.579)$, respectively]. There was also no significant difference in the occurrence of hepatotoxicity $[1.2 \%$ and $1.4 \%$ on the third day $(P=1.000) ; 3.6 \%$ and $4.1 \%$ at EOT $(P=1.000)$, respectively].

\section{Discussion}

Recent guidelines $[4,5]$ suggest a loading dose of $25-30 \mathrm{mg} / \mathrm{kg}$ to achieve the targeted range for treatment with vancomycin. In our study, however, the proportions of patients achieving $10-20 \mu \mathrm{g} / \mathrm{mL}$ and $15-20 \mu \mathrm{g} / \mathrm{mL}$ at $48 \mathrm{~h}$ after the first dose were $56.9 \%$ and $5.6 \%$, respectively, in patients with an eGFR $\geq 90 \mathrm{~mL} / \mathrm{min} / 1.73 \mathrm{~m}^{2}$ who received a regimen with a loading dose of $25 \mathrm{mg} / \mathrm{kg}$. There was no significant difference in the $\mathrm{C}_{\mathrm{min}}$ between the regimen with and without a loading dose. Rosini et al. [15] reported that the $12-h C_{m i n}$ allowed a significantly greater proportion of patients to achieve $15 \mu \mathrm{g} / \mathrm{mL}$ among patients with a loading dose of $30 \mathrm{mg} / \mathrm{kg}$ followed by $15 \mathrm{mg} / \mathrm{kg}$ twice daily compared with those without a loading dose. However, the effect of the loading dose was attenuated at the steady state, and only $20 \%$ of patients with a loading dose attained the target $\mathrm{C}_{\text {min }}$ at steady state. Most of their study patients also had a high $\mathrm{CL}_{\mathrm{cr}}$ (mean $93 \mathrm{~mL} / \mathrm{min}$ ). However, in a study including patients with deteriorated renal function, a loading dose resulted in a higher concentration at steady state $[16,17]$. In patients with deteriorated renal function, not only a loading dose but also a maintenance dose had a significant impact on the $\mathrm{C}_{\min }$.

Why the $\mathrm{C}_{\text {min }}$ was low in our study might be explained by only three obese patients being included. Pharmacokinetic (PK) data indicated a larger volume of distribution and accelerated renal clearance of vancomycin in obese patients [18], which might justify a weight-based dosing regimen. However, a study using weight-based regimens by Reynolds et al. [19] reported a $\mathrm{C}_{\min }>20 \mu \mathrm{g} / \mathrm{mL}$ in approximately $50 \%$ of obese patients. Richardson et al. [20] reported that increasing BMI categories were associated with a $C_{\min }>20 \mu \mathrm{g} / \mathrm{mL}$. Leong et al. [21] demonstrated that an adjusted body weight was more accurate at predicting vancomycin clearance in obese individuals.

A loading dose alone may not be sufficient to increase the $C_{\text {min }}$ measured $48 \mathrm{~h}$ after the initial dose in patients without decreased vancomycin clearance. However, the main purpose of a loading dose is not to obtain the target $\mathrm{C}_{\text {min }}$ at steady state, but the rapid achievement of a therapeutic concentration within 12-24 h [15]. To maintain a high concentration thereafter, an increase in the maintenance dose from $15 \mathrm{mg} / \mathrm{kg}$ to $20 \mathrm{mg} / \mathrm{kg}$ might be required [22]. Many studies reported a higher achievement of a $C_{\min }>15 \mu \mathrm{g} / \mathrm{mL}$ after the first dose in patients with a loading dose compared with patients without a loading dose [10, 15, 23, 24]. Casapao et al. [25] evaluated the association between the day 1 vancomycin exposure profile and outcomes among patients with MRSA infective endocarditis, and an AUC/MIC of < 600 was independently associated with failure. 
Few studies have focused on the use of a loading dose to increase clinical efficacy for the treatment of MRSA infections. Jeon et al. [26] reported an initial daily dose per weight $<40 \mathrm{mg} / \mathrm{kg}$ was a strong risk factor for vancomycin non-responsiveness in patients with MRSA pneumonia. Wesolek et al. [27] reported that an initial dose $>20 \mathrm{mg} / \mathrm{kg}$ led to a faster resolution of systematic inflammatory response syndrome (> 20 mg/ $\mathrm{kg}: 67 \mathrm{~h}$ vs $\leq 20$ mg/kg: 109 h). In our study, a loading dose increased the rate of early clinical response at 48-96 h after the start of therapy. However, there was no significant difference in clinical success at EOT between the regimen with and without a loading dose. Clinical response beyond $72 \mathrm{~h}$ of treatment can be affected by changes in the vancomycin dose later in therapy, based on the initial TDM conducted. Indeed, the achievement rate of target $\mathrm{C}_{\text {min }}$ of $10-20 \mu \mathrm{g} / \mathrm{mL}$ was increased from $7.4 \%$ to $74.1 \%$ of patients in whom the dosage was increased after initial TDM in our study.

PK analysis indicated that a loading dose of $25-30 \mathrm{mg} / \mathrm{kg}$ could be applied irrespective of renal function [28]. Clinicians, however, tend to be reluctant to use a loading dose, especially in patients with decreased renal function, for fear of causing renal injury. Alvarez et al. [10] demonstrated that all patients with a loading dose who presented with decreased vancomycin clearance before the administration of vancomycin had an elevated serum concentration $(>28 \mu \mathrm{g} / \mathrm{mL})$ in the first $24 \mathrm{~h}$ of treatment. These patients, however, did not have nephrotoxicity. Although prolonged exposure to elevated $C_{\min }$ causes nephrotoxicity, a temporary increase in the $C_{\min }$ with an initial loading dose might not cause nephrotoxicity. Marvin et al. [29] reported that a loading dose $>20 \mathrm{mg} / \mathrm{kg}$ was not associated with increased nephrotoxicity in patients with a $\mathrm{CL}_{\mathrm{cr}}<30 \mathrm{~mL} / \mathrm{min}$ compared with a standard dosing regimen.

\section{Limitations}

This study had some limitations. First, we did not measure the $C_{\min } 24 \mathrm{~h}$ after the first dose, and the early attainment of the target $\mathrm{C}_{\mathrm{min}}$ with a loading dose was not confirmed. Second, early clinical responses were evaluated at $48-72 \mathrm{~h}$ after the first dose. Although an early clinical response was defined as improvement at 48-72 h after the start of therapy in patients with acute bacterial skin and skin-structure infections [13], a significantly lower response rate in respiratory tract infection in our study might be caused by this early clinical response evaluation. Third, APACHE II scores were approximately 8.0, indicating mild-to-moderate severity. Although the Infectious Diseases Society of America guidelines ${ }^{3}$ recommend a loading dose for seriously ill patients, the efficacy of a loading dose was not confirmed in severely ill patients in our study. Fourth, patients with an eGFR $\geq 90$ $\mathrm{mL} / \mathrm{min} / 1.73 \mathrm{~m}^{2}$ were included in our study, which might explain the low $C_{\mathrm{min}}$, value observed, and thus exaggerate the weakness of the regimen without a loading dose.

\section{Conclusions}

In conclusion, a loading dose of $25 \mathrm{mg} / \mathrm{kg}$ followed by $15 \mathrm{mg} / \mathrm{kg}$ twice daily did not achieve the optimal $\mathrm{C}_{\text {min }}$ at steady state in patients with normal renal function. However, higher early clinical responses were obtained by a loading dose compared with traditional dosing, possibly because of a prompt but temporary achievement of the optimal concentration.

\section{Abbreviations}

$\mathrm{C}_{\min }$ : trough concentration; EOT: end of therapy; MRSA: methicillin-resistant Staphylococcus aureus; CLcr: creatinine clearance; eGFR: estimated glomerular filtration rate; TDM: therapeutic drug monitoring; MR-CNS: methicillin-resistant coagulase-negative Staphylococci; WBC: white blood cell; CRP: C-reactive protein; Cre: serum creatinine; AST: aspartate aminotransferase; ALT: alanine aminotransferase; BMI: Body mass index; OR: odds ratio; Cl: confidence interval; APACHE: Acute Physiology and Chronic Health Evaluation; PK: Pharmacokinetic

\section{Declarations}

\section{Ethics approval and consent to participate}

The study was approved by the Institutional Review Board of Hyogo College of Medicine (No. 2239). The institutional review board waived the requirement for informed consent from patients included in this study.

\section{Consent for publication}

Not applicable.

\section{Availability of data and material}

The datasets used and/or analyzed during the current study are available from the corresponding author on reasonable request. 


\section{Competing interests}

1. Takesue has received grant support from Shionogi \& Co., Ltd., and payment for lectures from Astellas Pharma Inc., and MSD Japan. Other authors have no conflict of interest to declare.

\section{Funding}

This research received no specific grant from any funding agency in the public, commercial, or not-for-profit sectors.

\section{Authors' contributions}

TU was involved in the conception of the study, collection, analysis and interpretation of data, the creation of new software used in the work, draft the work and substantively revised of the manuscript. YT was involved in the design of the study and draft the work. KN, KI, Kaori Ishikawa, YT, KY, YW, TT, NO, Yoshiko Takahashi, MI, SS, HI, MT and TK contributed to the data collection and interpretation. All authors had substantial input to the drafting and review of the manuscript and approved the final version prior to publication.

\section{Acknowledgements}

We thank Edanz Group (www.edanzediting.com/ac) for editing a draft of this manuscript.

\section{References}

1. Mizuno S, Iwami M, Kunisawa S, et al. Comparison of national strategies to reduce meticillin-resistant Staphylococcus aureus infections in Japan and England. J Hosp Infect. 2018; 100: 280-298. doi: 10.1016/j.jhin.2018.06.026.

2. Kramer TS, Schröder C, Behnke M, et al. Decrease of methicillin resistance in Staphylococcus aureus in nosocomial infections in Germany-a prospective analysis over 10 years. J Infect. 2019; 78: 215-219. doi: 10.1016/j.jinf.2018.12.005.

3. Cassini A, Högberg LD, Plachouras D, et al. Attributable deaths and disability-adjusted life-years caused by infections with antibiotic-resistant bacteria in the EU and the European Economic Area in 2015: a population-level modelling analysis. Lancet Infect Dis. 2019;19: 56-66. doi: 10.1016/S1473-3099(18)30605-4.

4. Rybak MJ, Lomaestro BM, Rotschafer JC, et al. Vancomycin therapeutic guidelines: a summary of consensus recommendations from the infectious diseases Society of America, the American Society of Health-System Pharmacists, and the Society of Infectious Diseases Pharmacists. Clin Infect Dis. 2009; 49: 325-7. doi: 10.1086/600877.

5. Matsumoto K, Takesue Y, Ohmagari N, et al. Practice guidelines for therapeutic drug monitoring of vancomycin: a consensus review of the Japanese Society of Chemotherapy and the Japanese Society of Therapeutic Drug Monitoring. J Infect Chemother. 2013; 19: 365-80. doi: 10.1007/s10156-013-0599-4.

6. Sakoulas G, Gold HS, Cohen RA, Venkataraman L, Moellering RC, Eliopoulos GM. Effects of prolonged vancomycin administration on methicillinresistant Staphylococcus aureus (MRSA) in a patient with recurrent bacteraemia. J Antimicrob Chemother. 2006; 57: 699-704.

7. Kullar R, Davis SL, Taylor TN, Kaye KS, Rybak MJ: Effects of targeting higher vancomycin trough levels on clinical outcomes and costs in a matched patient cohort. 2012; 32: 195-20. doi: 10.1002/j.1875-9114.2011.01017.

8. Itani KM, Dryden MS, Bhattacharyya H, Kunkel MJ, Baruch AM, Weigelt JA. Efficacy and safety of linezolid versus vancomycin for the treatment of complicated skin and soft-tissue infections proven to be caused by methicillin-resistant Staphylococcus aureus. Am J Surg. 2010; 199 : 804-16. doi: 10.1016/j.amjsurg.2009.08.045.

9. Wunderink RG, Niederman MS, Kollef MH, et al. Linezolid in methicillin-resistant Staphylococcus aureus nosocomial pneumonia: a randomized, controlled study. Clin Infect Dis. 2012; 54: 621-9. doi: 10.1093/cid/cir895

10. Álvarez O, Plaza-Plaza JC, Ramirez M, Peralta A, Amador CA, Amador R. Pharmacokinetic Assessment of Vancomycin Loading Dose in Critically III Patients. Antimicrob Agents Chemother. 2017; 61. pii: e00280-17. doi: 10.1128/AAC.00280-17.

11. Pea F, Viale P. Bench-to-bedside review: Appropriate antibiotic therapy in severe sepsis and septic shock-does the dose matter? Crit Care. 2009; 13: 214. doi: $10.1186 /$ cc7774

12. Reardon J, Lau TT, Ensom MH. Vancomycin loading doses: a systematic review. Ann Pharmacother. 2015; 49: 557-65. doi: $10.1177 / 1060028015571163$ 
13. Moran GJ, Fang E, Corey GR, Das AF, De Anda C, Prokocimer P. Tedizolid for 6 days versus linezolid for 10 days for acute bacterial skin and skinstructure infections (ESTABLISH-2): a randomised, double-blind, phase 3, non-inferiority trial. Lancet Infect Dis. 2014; 14: 696-705. doi: 10.1016/S1473-3099(14)70737-6.

14. Wayne, PA. Clinical and Laboratory Standards Institute: Performance Standards for Antimicrobial Susceptibility Testing; $28^{\text {th }}$ Edition Informational Supplement. CLSI, M02 and M07, 2018.

15. Rosini JM, Laughner J, Levine BJ, Papas MA, Reinhardt JF, Jasani NB. A randomized trial of loading vancomycin in the emergency department. Ann Pharmacother. 2015; 49: 6-13. doi: 10.1177/1060028014556813.

16. Golenia BS, Levine AR, Moawad IM, Yeh DD, Arpino PA. Evaluation of a vancomycin dosing nomogram based on the Modification of Diet in Renal Disease equation in intensive care unit patients. J Crit Care. 2013; 28: 710-6. doi: 10.1016/j.jcrc.2013.01.004.

17. Tuon FF, Romero R, Gasparetto J, Cieslinski J. Vancomycin trough level and loading dose. Infect Drug Resist. 2018; 11: 2393-2396. doi: 10.2147/IDR.S184897.

18. Grace E. Altered vancomycin pharmacokinetics in obese and morbidly obese patients: what we have learned over the past 30 years. J Antimicrob Chemother. 2012; 67: 1305-10. doi: 10.1093/jac/dks066.

19. Reynolds DC, Waite LH, Alexander DP, DeRyke CA. Performance of a vancomycin dosage regimen developed for obese Am J Health Syst Pharm. 2012; 69: 944-50. doi: 10.2146/ajhp110324.

20. Richardson J, Scheetz M, O'Donnell EP. The association of elevated trough serum vancomycin concentrations with obesity. J Infect Chemother. 2015; 21: 507-11. doi: 10.1016/j.jiac.2015.03.007.

21. Leong JV, Boro MS, Winter M. Determining vancomycin clearance in an overweight and obese Am J Health Syst Pharm. 2011; 68: 599-603. doi: 10.2146/ajhp100410.

22. Katip Bpharm W, Jaruratanasirikul S, Pattharachayakul S, Wongpoowarak W, Jitsurong A. Initial dosage regimen of vancomycin for septic shock patients: a pharmacokinetic study and Monte Carlo simulation. J Med Assoc Thai. 2014; 97: 1209-19.

23. Wang JT, Fang CT, Chen YC, Chang SC. Necessity of a loading dose when using vancomycin in critically ill patients. J Antimicrob Chemother. 2001; 47: 246.

24. Li J, Udy AA, Kirkpatrick CM, Lipman J, Roberts JA. Improving vancomycin prescription in critical illness through a drug use evaluation process: a weight-based dosing intervention study. Int J Antimicrob Agents. 2012; 39: 69-72. doi: 10.1016/j.ijantimicag.2011.08.017.

25. Casapao AM, Lodise TP, Davis SL, et al. Association between vancomycin day 1 exposure profile and outcomes among patients with methicillinresistant Staphylococcus aureus infective endocarditis. Antimicrob Agents Chemother. 2015; 59: 2978-85. doi: 10.1128/AAC.03970-14.

26. Jeon YL, Kim MH, Yang HS, Kang SY, Lee WI. Optimum initial loading dose of vancomycin for pneumonia caused by methicillin-resistant Staphylococcus aureus. J Infect. 2016; 72: 115-8. doi: 10.1016/j.jinf.2015.09.010.

27. Wesolek JL, McNorton K, Delgado G Jr, Giuliano CA. Effect of vancomycin initial dosing on time to systemic inflammatory response syndrome resolution in patients with methicillin-resistant Staphylococcus aureus bacteremia. J Chemother. 2018; 30: 101-106. doi: 10.1080/1120009X.2017.1389807.

28. Roberts JA, Taccone FS, Lipman J. et al. Understanding PK/PD. Intensive Care Med. 2016; 42: 1797-1800.

29. Marvin JL, Levine BJ, Papas M, Rosini JM. An Evaluation of the Incidence of Nephrotoxicity After a Loading Dose of Vancomycin in Patients With Severe Renal Impairment. J Emerg Med. 2019: S0736-4679: 30226-4. doi: 10.1016/j.jemermed.2019.03.020.

\section{Tables}

Table 1. Baseline demographics of patients included in the pharmacokinetics, safety, and clinical efficacy analyses. 


\begin{tabular}{|c|c|c|c|c|c|c|c|c|c|}
\hline & \multirow{3}{*}{$\begin{array}{c}\text { Regimen } \\
\text { without a } \\
\text { loading dose } \\
(\mathrm{n}=84)\end{array}$} & \multirow{3}{*}{$\begin{array}{c}\text { Regimen } \\
\text { with a loading } \\
\text { dose ( } \mathrm{n}=73)\end{array}$} & \multirow[b]{3}{*}{$\begin{array}{l}\mathrm{P}- \\
\text { value }\end{array}$} & \multirow{2}{*}{\multicolumn{3}{|c|}{ All infections $\quad(n=82)$}} & \multirow{2}{*}{\multicolumn{3}{|c|}{ MRSA infections ( $\mathrm{n}=55$ ) }} \\
\hline & & & & & & & & & \\
\hline & & & & $\begin{array}{l}\text { Regimen } \\
\text { without a } \\
\text { loading dose } \\
(\mathrm{n}=46)\end{array}$ & $\begin{array}{c}\text { Regimen } \\
\text { with a } \\
\text { loading dose } \\
(\mathrm{n}=36)\end{array}$ & $\begin{array}{c}\mathrm{P}- \\
\text { value }\end{array}$ & $\begin{array}{c}\text { Regimen } \\
\text { without a } \\
\text { loading dose } \\
(\mathrm{n}=32)\end{array}$ & $\begin{array}{l}\text { Regimen } \\
\text { with a } \\
\text { loading } \\
\text { dose } \\
(n=23)\end{array}$ & $\begin{array}{c}\mathrm{P}- \\
\text { value }\end{array}$ \\
\hline Sex male (\%) & 53 (63.1\%) & 40 (54.8\%) & 0.291 & 31 (67.4\%) & 19 (52.8\%) & 0.178 & 23 (71.9\%) & $12(52.2 \%)$ & 0.134 \\
\hline Age (range) (years) & $65.1 \pm 12.0$ & $61.5 \pm 13.5$ & 0.077 & $65.7 \pm 11.6$ & $64.2 \pm 13.0$ & 0.469 & $64.0 \pm 10.4$ & $63.2 \pm 13.7$ & 0.801 \\
\hline $\begin{array}{l}\text { Body weight (range) } \\
\text { (kg) }\end{array}$ & $56.7 \pm 12.6$ & $54.3 \pm 10.8$ & 0.201 & $56.4 \pm 13.2$ & $53.4 \pm 9.2$ & 0.097 & $58.3 \pm 14.4$ & $52.6 \pm 9.6$ & 0.077 \\
\hline Body mass index $\geq 25$ & $12(14.3 \%)$ & $11(15.1 \%)$ & 0.890 & 5 (10.9\%) & $4(11.1 \%)$ & 1.000 & $4(12.5 \%)$ & $3(13.0 \%)$ & 1.000 \\
\hline APACHE II score & $8.0 \pm 4.5$ & $8.7 \pm 5.5$ & 0.528 & $8.7 \pm 5.1$ & $9.8 \pm 5.8$ & 0.451 & $8.3 \pm 4.5$ & $8.5 \pm 5.1$ & 0.966 \\
\hline $\begin{array}{l}\text { Estimated glomerular } \\
\text { filtration rate (range) } \\
\left(\mathrm{mL} / \mathrm{min} / 1.73 \mathrm{~m}^{2}\right)\end{array}$ & $117.6 \pm 40.7$ & $120.7 \pm 27.1$ & 0.586 & $122.9 \pm 29.4$ & $120.8 \pm 23.2$ & 0.159 & $123.3 \pm 56.6$ & $120.4 \pm 24.1$ & 0.820 \\
\hline \multicolumn{10}{|l|}{ Type of infection } \\
\hline Blood stream & 22 (26.2\%) & 30 (41.1\%) & 0.048 & $13(28.3 \%)$ & $17(47.2 \%)$ & 0.077 & $6(18.8 \%)$ & $6(26.1 \%)$ & 0.516 \\
\hline Respiratory & 15 (17.9\%) & $6(8.2 \%)$ & 0.077 & $14(30.4 \%)$ & $6(16.7 \%)$ & 0.150 & $14(43.8 \%)$ & $6(26.1 \%)$ & 0.179 \\
\hline Intraabodominal & $12(14.3 \%)$ & $3(4.1 \%)$ & 0.054 & 10 (21.7\%) & $1(2.8 \%)$ & 0.019 & $4(12.5 \%)$ & $0(0.0 \%)$ & 0.131 \\
\hline Skin \& soft tissue & $9(10.7 \%)$ & $8(11.0 \%)$ & 0.961 & 7 (15.2\%) & $8(22.2 \%)$ & 0.416 & $6(18.8 \%)$ & $8(34.8 \%)$ & 0.178 \\
\hline $\begin{array}{l}\text { Osteomyelitis and } \\
\text { arthritis }\end{array}$ & $14(16.7 \%)$ & $10(13.7 \%)$ & 0.606 & $5(10.9 \%)$ & $3(8.3 \%)$ & 1.000 & $4(12.5 \%)$ & $3(13.0 \%)$ & 0.630 \\
\hline Mediastinitis & $3(3.6 \%)$ & $5(6.8 \%)$ & 0.474 & $1(2.2 \%)$ & $2(5.6 \%)$ & 0.579 & $1(3.1 \%)$ & $1(4.3 \%)$ & 0.666 \\
\hline $\begin{array}{l}\text { Unknown (empiric } \\
\text { therapy) }\end{array}$ & $13(16.7 \%)$ & 15 (20.5\%) & 0.408 & - & - & - & - & - & - \\
\hline \multicolumn{10}{|c|}{ Isolated Gram-positive cocci } \\
\hline MRSA & 39 (59.1\%) & $28(48.3 \%)$ & 0.267 & $32(69.6 \%)$ & $23(63.9 \%)$ & 0.587 & 32 & 23 & \\
\hline MSSA & $6(5.1 \%)$ & $8(13.8 \%)$ & 0.392 & - & - & - & - & - & \\
\hline MR-CNS & 7 (10.6\%) & $12(20.7 \%)$ & 0.120 & 7 (15.2\%) & $12(33.3 \%)$ & 0.054 & - & - & \\
\hline MS-CNS & $2(5.0 \%)$ & $4(6.9 \%)$ & 1.000 & - & - & - & - & - & \\
\hline Enterococcus faecalis & $2(5.0 \%)$ & $1(1.7 \%)$ & 1.000 & - & - & - & - & - & \\
\hline $\begin{array}{l}\text { Enterococcus } \\
\text { faecium }\end{array}$ & $8(52.1 \%)$ & $1(1.7 \%)$ & 0.090 & $7(15.2 \%)$ & $1(2.8 \%)$ & 0.073 & - & - & \\
\hline Streptococcus sp & 1 (5.5\%) & $2(3.4 \%)$ & 0.541 & - & - & - & - & - & \\
\hline Bacillus sp & $2(3.0 \%)$ & $3(5.2 \%)$ & 0.589 & - & - & - & - & - & \\
\hline
\end{tabular}

Age, body weight and estimated glomerular filtration rate are expressed as the mean \pm S.D. and range.

MRSA; Methicillin-resistant Staphylococcus aureus, MSSA; Methicillin-sensitive Staphylococcus aureus, MR-CNS; Methicillin-resistant coagulase-negative Staphylococci, MS-CNS; Methicillin-sensitive coagulase-negative Staphylococci.

Table 2. Vancomycin initial trough concentration $\left(\mathrm{C}_{\mathrm{min}}\right)$ in each regimen group 


$\begin{array}{cccc}\text { Median } & 10.2(7.9-12.5,3.2-19.8) & 10.4(8.8-12.3,5.1-17.2) & 0.538\end{array}$

No. of patient according to the initial $\mathrm{C}_{\min }$ categories (\%)

\begin{tabular}{lccc}
\hline$<10 \mu \mathrm{g} / \mathrm{mL}$ & $42(51.9 \%)$ & $31(43.1 \%)$ & 0.277 \\
\hline $10-15 \mu \mathrm{g} / \mathrm{mL}$ & $31(38.3 \%)$ & $37(51.4 \%)$ & 0.103 \\
\hline $15-20 \mu \mathrm{g} / \mathrm{mL}$ & $8(9.9 \%)$ & $4(5.6 \%)$ & 0.321 \\
\hline$\geq 20 \mu \mathrm{g} / \mathrm{mL}$ & $0(0.0 \%)$ & $0(0.0 \%)$ & -
\end{tabular}

Table 3. Efficacy and mortality in patients with MRSA, Enterococcus faecium, or methicillin-resistant coagulase-negative staphylococci (MR-CNS) infections treated by vancomycin with or without a loading dose.

\begin{tabular}{|c|c|c|c|c|c|c|c|c|c|c|c|c|}
\hline \multirow[t]{2}{*}{ Clinical results } & \multicolumn{3}{|c|}{ MRSA } & \multicolumn{3}{|c|}{ Enterococcus faecium } & \multicolumn{3}{|c|}{ MR-CNS } & \multicolumn{3}{|c|}{ Total } \\
\hline & $\begin{array}{c}\text { Regimen } \\
\text { without a } \\
\text { loading } \\
\text { dose }\end{array}$ & $\begin{array}{l}\text { Regimen } \\
\text { with } \\
\text { a loading } \\
\text { dose }\end{array}$ & $\begin{array}{c}\mathrm{P}- \\
\text { value }\end{array}$ & $\begin{array}{c}\text { Regimen } \\
\text { without a } \\
\text { loading } \\
\text { dose }\end{array}$ & $\begin{array}{l}\text { Regimen } \\
\text { with } \\
\text { a loading } \\
\text { dose }\end{array}$ & $\begin{array}{c}\mathrm{P}- \\
\text { value }\end{array}$ & $\begin{array}{c}\text { Regimen } \\
\text { without a } \\
\text { loading } \\
\text { dose }\end{array}$ & $\begin{array}{l}\text { Regimen } \\
\text { with } \\
\text { a loading } \\
\text { dose }\end{array}$ & $\begin{array}{c}\mathrm{P}- \\
\text { value }\end{array}$ & $\begin{array}{c}\text { Regimen } \\
\text { without a } \\
\text { loading } \\
\text { dose }\end{array}$ & $\begin{array}{l}\text { Regimen } \\
\text { with } \\
\text { a loading } \\
\text { dose }\end{array}$ & $\begin{array}{l}\text { P- } \\
\text { value }\end{array}$ \\
\hline $\begin{array}{l}\text { Early clinical } \\
\text { response }\end{array}$ & $\begin{array}{c}16 / 32 \\
(50.0 \%)\end{array}$ & $\begin{array}{c}18 / 23 \\
(78.3 \%)\end{array}$ & 0.033 & $\begin{array}{c}5 / 7 \\
(71.4 \%)\end{array}$ & $\begin{array}{c}0 / 1 \\
(0.0 \%)\end{array}$ & 0.375 & $\begin{array}{c}5 / 7 \\
(71.4 \%)\end{array}$ & $\begin{array}{c}9 / 12 \\
(75.0 \%)\end{array}$ & 1.000 & $\begin{array}{c}26 / 46 \\
(56.5 \%)\end{array}$ & $\begin{array}{c}27 / 36 \\
(75.0 \%)\end{array}$ & 0.082 \\
\hline $\begin{array}{c}\text { Clinical } \\
\text { success at the } \\
\text { end of therapy }\end{array}$ & $\begin{array}{c}18 / 32 \\
(56.3 \%)\end{array}$ & $\begin{array}{c}16 / 23 \\
(69.6 \%)\end{array}$ & 0.316 & $\begin{array}{c}7 / 7 \\
(100.0 \%)\end{array}$ & $\begin{array}{c}0 / 1 \\
(0.0 \%)\end{array}$ & 0.125 & $\begin{array}{c}7 / 7 \\
(100.0 \%)\end{array}$ & $\begin{array}{c}10 / 12 \\
(83.3 \%)\end{array}$ & 0.509 & $\begin{array}{c}32 / 46 \\
(69.6 \%)\end{array}$ & $\begin{array}{c}26 / 36 \\
(72.2 \%)\end{array}$ & 0.793 \\
\hline $\begin{array}{l}\text { Microbiological } \\
\text { success }\end{array}$ & $\begin{array}{c}18 / 32 \\
(56.3 \%)\end{array}$ & $\begin{array}{c}16 / 22^{*} \\
(72.7 \%)\end{array}$ & 0.218 & $\begin{array}{c}5 / 7 \\
(71.4 \%)\end{array}$ & $\begin{array}{c}0 / 1 \\
(0.0 \%)\end{array}$ & 0.375 & $\begin{array}{c}5 / 7 \\
(71.4 \%)\end{array}$ & $\begin{array}{c}10 / 12 \\
(83.3 \%)\end{array}$ & 1.000 & $\begin{array}{c}30 / 46 \\
(65.2 \%)\end{array}$ & $\begin{array}{c}27 / 35 \\
(77.1 \%)\end{array}$ & 0.244 \\
\hline $\begin{array}{l}28 \text { days } \\
\text { mortality }\end{array}$ & $\begin{array}{c}3 / 32 \\
(9.4 \%)\end{array}$ & $\begin{array}{c}1 / 23 \\
(4.3 \%)\end{array}$ & 0.632 & $\begin{array}{c}0 / 7 \\
(0.0 \%)\end{array}$ & $\begin{array}{c}1 / 1 \\
(100 \%)\end{array}$ & 0.125 & $\begin{array}{c}0 / 7 \\
(0.0 \%)\end{array}$ & $\begin{array}{c}1 / 12 \\
(8.3 \%)\end{array}$ & 1.000 & $\begin{array}{c}3 / 46 \\
(6.5 \%)\end{array}$ & $\begin{array}{c}3 / 36 \\
(8.3 \%)\end{array}$ & 1.000 \\
\hline
\end{tabular}

*: One patient in whom culture results after start of therapy were not obtained was excluded

Table 4. Variable factors associated with an early clinical response in patients with MRSA, Enterococcus faecium, or methicillin-resistant coagulase-negative staphylococci (MR-CNS) : univariate and multivariate analyses. 
No of patients with early clinical response (\%)

\begin{tabular}{|c|c|c|c|c|c|}
\hline & \multicolumn{2}{|c|}{ (\%) } & \multirow[t]{2}{*}{ value } & \multirow[t]{2}{*}{$(95 \% \mathrm{CI})$} & \multirow[t]{2}{*}{ CI) } \\
\hline & $\begin{array}{l}\text { Patients with } \\
\text { factor }\end{array}$ & $\begin{array}{l}\text { Patients without } \\
\text { factor }\end{array}$ & & & \\
\hline Sex (male) & $31 / 49(63.3 \%)$ & $22 / 33(66.7 \%)$ & 0.752 & $0.477(0.165-1.378)$ & \\
\hline Age ( $>65$ years) & $29 / 45(64.4 \%)$ & $24 / 37$ (64.9\%) & 0.968 & $0.770(0.282-2.099)$ & \\
\hline Body Mass Index $\square 18.5$ & $18 / 23(78.3 \%)$ & $35 / 59$ (59.3\%) & 0.107 & $1.493(0.418-5.334)$ & \\
\hline Body Mass Index $\geq 25$ & $5 / 9(55.6 \%)$ & $48 / 73(65.8 \%)$ & 0.714 & $1.885(0.359-9.898)$ & \\
\hline Heart disease & $9 / 14(64.3 \%)$ & $44 / 68(64.7 \%)$ & 0.601 & $\begin{array}{l}3.300(0.373- \\
29.194)\end{array}$ & \\
\hline Diabetes mellitus & 10/13 (76.9\%) & $43 / 69(62.3 \%)$ & 0.364 & $\begin{array}{l}2.917(0.583- \\
14.603)\end{array}$ & \\
\hline Collagen disease & $4 / 11(36.4 \%)$ & $49 / 71(69.0 \%)$ & 0.046 & $0.159(0.037-0.693)$ & \\
\hline Chronic respiratory disease & $4 / 7$ (57.1\%) & $49 / 75(65.3 \%)$ & 0.694 & $0.303(0.047-1.958)$ & \\
\hline Liver cirrhosis/chronic hepatic dysfunction & $3 / 6(50.0 \%)$ & $50 / 76(65.8 \%)$ & 0.660 & $1.000(0.169-5.909)$ & \\
\hline Malignant tumor & $31 / 44(70.5 \%)$ & $22 / 38(57.9 \%)$ & 0.236 & $1.299(0.476-3.541)$ & \\
\hline Total parenteral nutrition & $10 / 21(47.6 \%)$ & 43/61 (70.5\%) & 0.059 & $0.148(0.039-0.557)$ & \\
\hline $\begin{array}{l}\text { Hypoalbuminemia (serum albumin }<2.5 \\
\text { g/dL) }\end{array}$ & $12 / 26(46.2 \%)$ & $41 / 56(73.2 \%)$ & 0.017 & $0.265(0.089-0.794)$ & \\
\hline Surgery within 28 days & $24 / 33(72.7 \%)$ & $29 / 49(59.2 \%)$ & 0.208 & $1.092(0.398-2.993)$ & \\
\hline Ventilator use & $3 / 12(25.0 \%)$ & $50 / 70(71.4 \%)$ & 0.003 & $0.104(0.020-0.553)$ & \\
\hline ICU stay & $3 / 10(30.0 \%)$ & $50 / 72(69.4 \%)$ & 0.029 & $0.106(0.011-1.008)$ & \\
\hline APACHE II score $>10$ & $11 / 27(40.7 \%)$ & $42 / 55(76.4 \%)$ & 0.002 & $0.162(0.053-0.498)$ & $0.188(0.057-0.616)$ \\
\hline Steroid use & $6 / 14(42.9 \%)$ & $47 / 68(69.1 \%)$ & 0.073 & $0.281(0.084-0.946)$ & \\
\hline Immunosuppressive therapy & $0 / 2(0.0 \%)$ & $53 / 80(66.3 \%)$ & 0.122 & $0.233(0.020-2.720)$ & \\
\hline Anticancer therapy & $6 / 8(75.0 \%)$ & $47 / 74(63.5 \%)$ & 0.706 & $1.000(0.226-4.420)$ & \\
\hline Blood stream infection & $20 / 30(66.7 \%)$ & $33 / 52(63.5 \%)$ & 0.770 & $1.116(0.360-3.457)$ & \\
\hline Respiratory tract infection & $9 / 20(45.0 \%)$ & $44 / 62(71.0 \%)$ & 0.035 & $0.265(0.089-0.794)$ & \\
\hline Intra-abdominal infection & $7 / 11(63.6 \%)$ & $46 / 71(64.8 \%)$ & 0.594 & $\begin{array}{l}1.535(0.151- \\
15.631)\end{array}$ & \\
\hline Skin \& soft tissue infection & $12 / 15(80.0 \%)$ & $41 / 67(61.2 \%)$ & 0.168 & $\begin{array}{l}4.594(0.946- \\
22.315)\end{array}$ & \\
\hline Osteomyelitis and arthritis & $3 / 8(37.5 \%)$ & $50 / 74(67.6 \%)$ & 0.124 & $0.646(0.180-2.315)$ & \\
\hline Mediastinitis & $2 / 3(66.7 \%)$ & $51 / 79(64.6 \%)$ & 0.716 & $0.477(0.063-3.626)$ & \\
\hline MRSA & $34 / 55$ (61.8\%) & 19/27 (70.4\%) & 0.447 & $0.270(0.055-1.327)$ & \\
\hline Loading dose regimen & $27 / 36(75.0 \%)$ & $26 / 46(56.5 \%)$ & 0.082 & $\begin{array}{l}3.373(1.126- \\
10.100)\end{array}$ & $4.829(1.441-16.188)$ \\
\hline Vancomycin, $\mathrm{MIC}<1 \mu \mathrm{g} / \mathrm{mL}$ & $8 / 13(61.5 \%)$ & $45 / 69(65.2 \%)$ & 0.516 & $1.197(0.279-5.132)$ & \\
\hline Vancomycin, MIC $2 \mu \mathrm{g} / \mathrm{mL}$ & $5 / 7$ (71.4\%) & $48 / 75(64.0 \%)$ & 0.522 & $1.406(0.255-7.746)$ & \\
\hline VCM initial $C_{\min } \geq 10 \mu \mathrm{g} / \mathrm{mL}$ & $32 / 49(65.3 \%)$ & $21 / 33(63.6 \%)$ & 0.877 & $1.418(0.519-3.873)$ & \\
\hline $\mathrm{VCM}$ initial $\mathrm{C}_{\min } \geq 15 \mu \mathrm{g} / \mathrm{mL}$ & $7 / 9(77.8 \%)$ & $46 / 73(63.0 \%)$ & 0.481 & $\begin{array}{l}2.095(0.221- \\
19.904)\end{array}$ & \\
\hline
\end{tabular}

95\% CI: 95\% confidence interval; APACHE II : Acute physiology and chronic health evaluation II score

Table 5 Variable factors associated with an early clinical response in patients with MRSA infections: univariate and multivariate analyses. 
No of patients with early clinical response (\%)

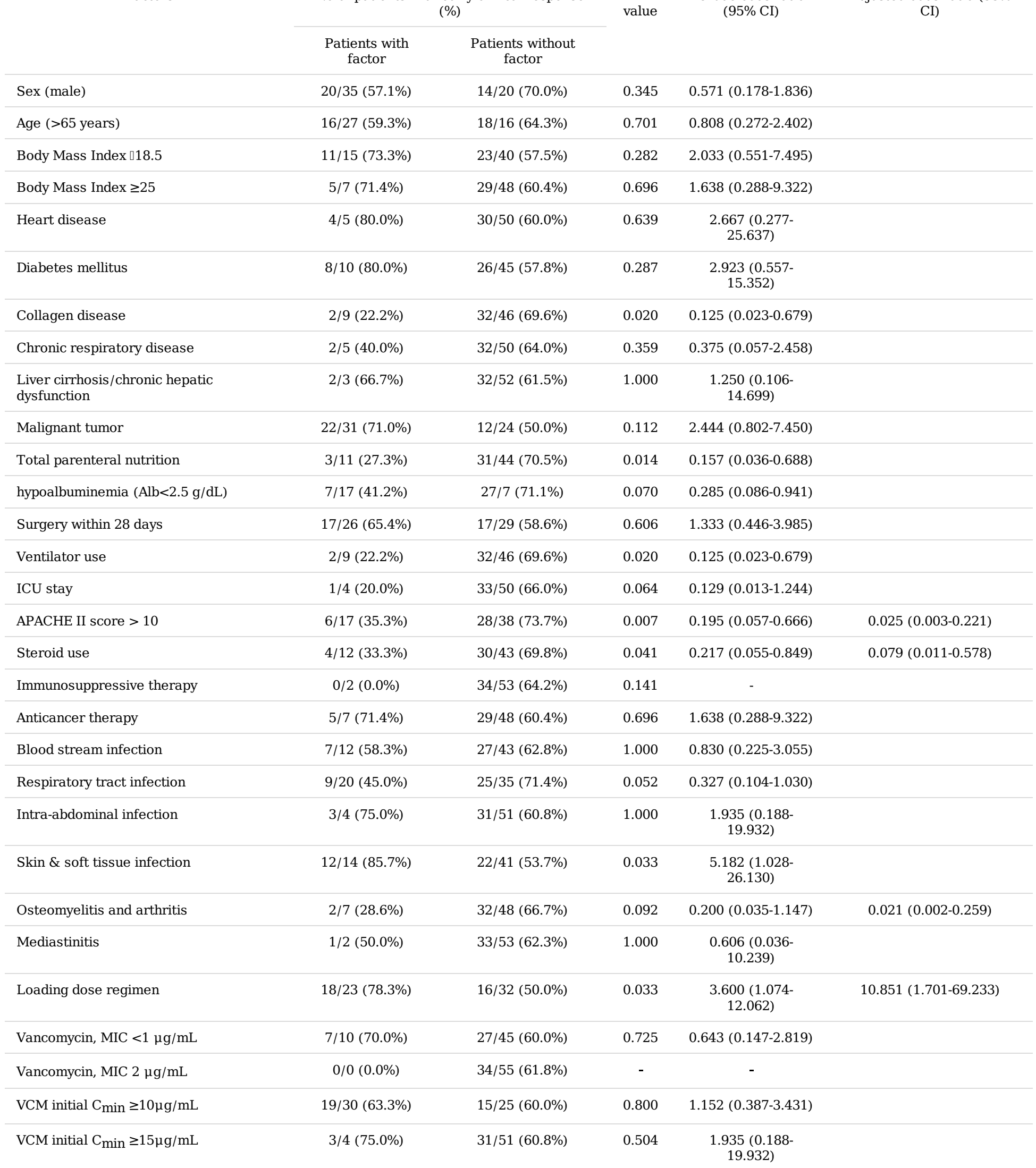

95\% CI: 95\% confidence interval; APACHE II : Acute physiology and chronic health evaluation II score 